\title{
The Relevance of Cluster Initiatives in Rural Areas: Regional Policy in Sweden
}

\author{
Linda Lundmark and Örjan Pettersson
}

\author{
Linda Lundmark, Department of Social and Economic Geography, Umeå University, Sweden \\ (linda.lundmark@geography.umu.se) \\ Örjan Pettersson, Department of Social and Economic Geography, Umeå University, Sweden \\ (orjan.pettersson@geography.umu.se)
}

\begin{abstract}
The relatively weak performance of sparsely populated areas has been given substantial attention in many regional, national and European Union initiatives. Many rural areas are struggling with development problems such as depopulation, advanced ageing, industrial restructuring and high levels of structural unemployment. In Sweden these issues are mainly associated with the difficulties in the non-metropolitan sparsely populated areas in the northern and southeastern parts. Here, the issue of implementing general cluster policies in sparsely populated regions in order to enhance their economic development is in focus. This research includes an overview of existing Swedish regional growth and development programmes that exemplify the current regional policies. It is found that the concepts of clusters and innovation systems have become important for policy on national and regional levels of government, but the understanding of the concepts is poor. In spite of regional variations in preconditions for cluster development, there are no clear regional modifications in the interpretation of clusters as described in the documents. One conclusion is that regional and local strategies to develop businesses in sparsely populated areas would benefit from using examples from non-metropolitan regions as a point of departure rather than using experiences drawn from high-tech industries located in metropolitan areas usually referenced in the international literature. The routine use of cluster and innovation systems in policy on the regional level underlines the need for more empirically based research on the preconditions for cluster development in sparsely populated areas.
\end{abstract}

Keywords: cluster theory, growth policy implementation, sparsely populated areas, regional development

\section{Introduction}

The cluster as a concept was introduced by Michael Porter in the beginning of the 1990s (Porter 1990, 1996, 1998), and the impact of the theory has been breathtaking to say the least. The ideas put forward by Porter have been adopted and developed both in research in economic geography and other related academic disciplines (Malmberg 2002, Malmberg and Maskell 2002). The interest has been remarkable and has also had an impact on policy making concerning industry policy and regional development (Karlsson 2008, Malmberg 2002, Swedish Agency for Economic and Regional Growth 2009). However, there has not been much attention in research directed towards the reality of businesses in sparsely populated regions. Nevertheless, the relatively weak performance of sparsely populated areas has been given substantial attention in many regional, national and European Union initiatives. Many rural areas are struggling with development problems such as depopulation, advanced ageing, industrial restructuring and high levels of structural unemployment (Pettersson 2002). Within a Swedish context, these issues are mainly associated with the difficulties in the non-metropolitan 
regions and generally sparsely populated areas in the northern and southeastern parts of the country (Figure 1). A diversification of the economy is often mentioned as important for the future development and special attention has been paid to promoting a better business environment for small and medium size companies (SMEs) in order to develop a new business structure, to increase entrepreneurship and hence stimulate new firms and employment opportunities. The latter point is largely related to the measures taken to improve people's knowledge in terms of how to start a new business and computer usage. These are also seen as conditions in which dynamic clusters are developed (Malmberg 2002, Malmberg and Power 2005, Porter 1996, 1998).

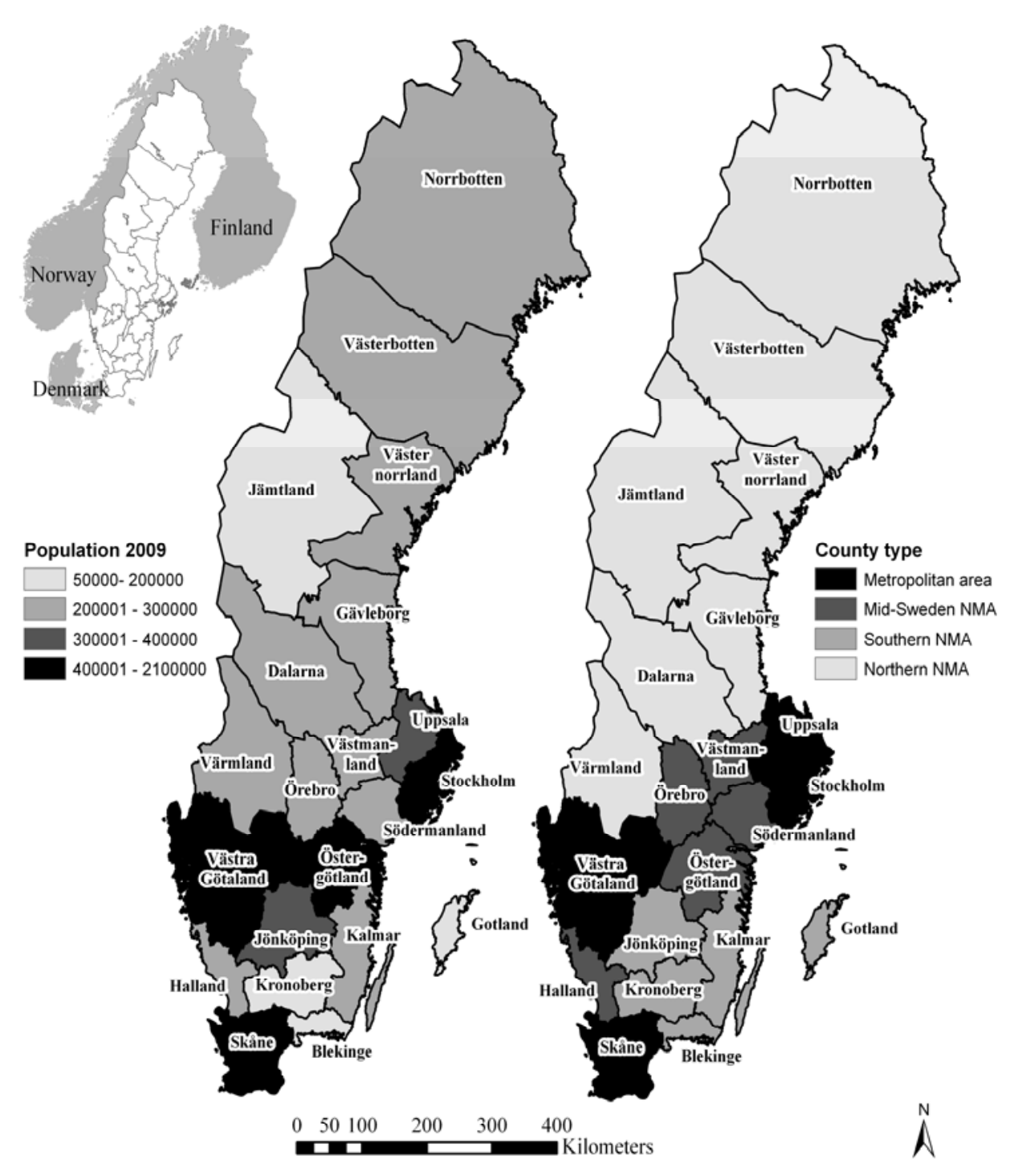

Figure 1. a) Population in Swedish counties in 2009. b) Division of counties into Metropolitan and non-metropolitan counties (NMA). Source: Statistics Sweden

This paper targets the issue of implementing general cluster policies in sparsely populated regions in order to enhance their economic development. The paper starts out by introducing some of the main themes regarding policy and cluster theory. Then an 
overview of the possible implementation options of policy informed by cluster ideas follows, and an overview of existing Swedish regional growth and development programmes ('Regional Growth Programme' - RTP; and 'Regional Development Programme' - RUP) are used to exemplify the current regional policies. Finally, a discussion of the possibilities versus the weaknesses of the cluster policy approach is presented with some reference to the use and misuse of the cluster ideas.

\section{Clusters, Innovativeness and Labour Mobility}

There are many interpretations of what a cluster is, departing from diverse viewpoints. However, they all explain different functions and benefits of clusters (Malmberg and Power 2005 offer an overview). The confusion produced by this flexible use of the concept has created difficulties in interpreting both what clusters are, and where the advantage actually lies (Malmberg and Power 2005). Despite the confusion around the concept, there is a mutual understanding among researchers that the presence of clusters in an economy is positive and an incentive for competitive advantage, regional development and knowledge creation (Bathelt et al. 2004, Malmberg and Maskell 2002). Michael Porter (1990, 1996, 1998, 2000) defines a cluster as a group of industries connected by specialized buyer-supplier relationships or related by technologies or skills. The most important agglomeration economies are dynamic rather than static and revolve around the capacity for innovation and learning (Porter 1996, 1998). The role of innovation has been emphasized as being the most important for clusters and cluster development (Malmberg and Power 2005) and according to Asheim et al. (2003) the ability to be innovative in a globalizing economy is vital for the competitiveness of SMEs. Innovativeness, however, is not restricted to high-tech industries alone but can also be achieved by traditional low-tech sectors. In current theory on innovation systems and cluster evolution, knowledge is regarded the most important resource in the economy and learning is the most important process (Steinsli and Spilling 2004).

According to Porter (1996), there are some options on how to encourage regional business development. Porter suggests that agglomeration economies at the cluster level have a profound influence on competition, particularly in more developed countries, and that the cost to access distant markets has decreased; increasing the companies' possibilities to sell their products outside the local and regional market.

Empirical research on the relationships between labour mobility, the presence of clusters and firm/plant performance is however scarce, although there are some notable exceptions (Boschma et al. 2008, Eriksson and Lindgren 2008, Eriksson et al. 2008). One overriding hypothesis is that labour mobility generates knowledge flows between firms and is thus important to the understanding of cluster dynamics. To begin with, Eriksson et al. (2008) find that the propensity of changing jobs within a local labour market increases with the size of the local labour market. This means that job changes are more likely to occur in large and diversified metropolitan regions than in smaller labour markets. Furthermore, the propensity increases if there is an agglomeration of firms in similar or related businesses (i.e. clusters). This effect is also observed in small labour markets, thereby indicating that localization economies are partly able to compensate for smallness. Eriksson and Lindgren (2008) further state that spatially close firms tied together by flows of labour between them outperform other similar firms within the same local labour market. This indicates that labour mobility between firms produces knowledge flows that are more important for the firm's competitiveness 
than simply spatial concentrations of similar or related firms usually assumed in many theories regarding cluster and localization economies. An inflow of related competences (i.e. not exactly the same or totally different from the skills already present within a certain workplace) to a plant substantially improves performance (Boschma et al. 2008). It is argued that, in contrast to an inflow of similar or unrelated competences to a plant, related competences broaden the skills portfolio represented within the work-place and thereby enhance competitiveness and increase productivity. Unrelated skills may contribute to productivity, but only if the person comes from within the same labour market. Furthermore, an inflow of labour from outside the region only stimulates productivity if it brings related skills.

Thus, for small labour markets outside the metropolitan regions and rural areas in general, spatial agglomerations of related and similar activities can enhance firms' and regions' performance, though it also seems important that the labour flows between the local firms consist of related skills and not only similar or unrelated competences. The same is relevant for an inflow of labour from outside the region. Otherwise there is an obvious risk of stagnant productivity and reduced competitiveness.

\section{Labour Markets Expansion and Cluster Policies}

In countries with few inhabitants spread over vast geographical areas it is important to have access to well developed communication systems facilitating commuting. This is because there is not a large enough population to be able to host all the competences and knowledge needed in the firms located in geographical clusters. The human and social capital vested in the population is the base on which the success of a region or area is built. However, one of the largest barriers for economic growth is the immobility of people. Local labour market expansion has been a popular target during recent years in Swedish regional politics (Sandow and Westin 2010). It is at the local level most mobility takes place because, among other things, people have accumulated place- or firm specific insider advantages, local knowledge and place attachment. With high degrees of place-specific investments, the cost of changing region or work is likely to exceed the potential benefits. Economic change and labour market development is geographically uneven which imply that local labour markets function differently depending on size and geographical location.

Porter (1996) argues that governments often hinder cluster formation and development by encouraging firms to locate in areas lacking supporting infrastructure and where they face competitive disadvantages. Such efforts result in high costs to governments and communities in terms of subsidies. Instead, regional policy should promote specialization, upgrading and trade among regions (Porter 1998). Since productivity is assumed to determine the wealth of a region, Porter further claims that governments must support initiatives that promote increased productivity. Governments must be able to supply high quality inputs such as an adequate physical infrastructure and well-educated communities. The three main dynamics of productivity, innovation and new business investment, and the specific benefits these bring to local firms and economies are essential to cluster development. In Porter's mind location continues to play an important role for the development of strong economies, as long as a region can maintain its exclusive critical mass. Government policy can assist sector interaction at a local level where the clusters operate. This is crucial for the development of local advantages, and agglomerations (Scott and Storper 2003). 


\section{The Geography of Regional Development in Sweden}

Sweden is a country with substantial differences regarding, for instance, population density and economic change. There are basically three metropolitan areas in Sweden. First and foremost, there is the capital region of Stockholm, where Stockholm county together with Uppsala is Sweden's largest and most dynamic local labour market (Figure 1). The other two metropolitan regions are represented by the counties of Västra Götaland (incl. Gothenburg) and Skåne (incl. Malmö and close to Denmark’s capital Copenhagen). These three regions together hold a slight majority of the country's population. However, in this paper, the focus is on the non-metropolitan areas as represented by the remaining 17 counties. Whereas the population has grown rapidly in the metropolitan regions, the more sparsely populated non-metropolitan counties as a group have experienced a much more moderate growth. Half of the non-metropolitan counties have in fact had negative population figures during the first decade of the 21st century. Even though data regarding, for example, employment, trade and industry does not reveal any dramatic differences between Sweden's counties, there are nevertheless some structural variations worth mentioning. In the non-metropolitan counties there is still a larger dependency on manufacturing, primary activities with related industries, and public sector services (Table 1). The metropolitan regions are characterized by higher shares of employment in the private service sectors. Furthermore, there are clear differences in education level where the non-metropolitan areas have a lower share of highly educated people.

Table 1: Key Figures for Classified Swedish Regions

\begin{tabular}{|c|c|c|c|c|c|c|}
\hline Variable: & $\begin{array}{l}\text { Sweden } \\
\text { MA }\end{array}$ & NMA & $\begin{array}{l}\text { Mid- } \\
\text { Sweden } \\
\text { NMA }\end{array}$ & $\begin{array}{l}\text { Southern } \\
\text { Sweden } \\
\text { NMA }\end{array}$ & $\begin{array}{l}\text { Northern } \\
\text { Sweden } \\
\text { NMA }\end{array}$ & Sweden \\
\hline Number of inhabitants 2009 (thousands) & 5,152 & 4,189 & 1,523 & 963 & 1,703 & 9,341 \\
\hline Population density 2009 (inh./sqkm) & 103.6 & 11.6 & 42.5 & 26.5 & 5.9 & 22.8 \\
\hline Population change 2000-2009 (\%) & 8.6 & 1.2 & 3.4 & 1.6 & -1.0 & 5.2 \\
\hline Pop. with higher education 2008 (\%)* & 21.5 & 14.6 & 15.3 & 13.7 & 14.4 & 18.4 \\
\hline Employed in private companies 2008 (\%) & 69.1 & 62.6 & 64.6 & 64.2 & 59.9 & 66.3 \\
\hline \multicolumn{7}{|l|}{ Share of employed in sectors (2007)**: } \\
\hline - Primary and secondary industries (\%) & 14.8 & 22.8 & 22.1 & 27.4 & 20.7 & 18.3 \\
\hline - Services to private companies (\%) & 17.8 & 10.5 & 11.4 & 9.2 & 10.4 & 14.6 \\
\hline - Other (\%) & 67.4 & 66.7 & 66.5 & 63.4 & 68.9 & 67.1 \\
\hline
\end{tabular}

MA: Metropolitan Area - NMA: Non-Metropolitan Area

*Persons 16-74 years of age with at least 3 years of university education

$* *$ Working population $16+$ years of age

Source: Statistics Sweden

However, there are also obvious variations within the non-metropolitan group. In general, the counties close to the metropolitan areas show a better performance than those in southeastern Sweden and northern Sweden. In particular, the northern nonmetropolitan counties are characterized by low population densities, long distances between major urban areas, structural ageing, depopulation and a relatively poor performance on most growth indicators. This has been a general tendency over several decades and also the basic motivation behind these parts of the country having been the main targets for traditional Swedish regional policy (Pettersson 2002). Nevertheless, the restructuring problems in developing from a society largely based on the region's 
natural resources (such as land, timber, ores and hydroelectric power) to 'the new economy' still remain, to some extent, and continue to have an effect on population development, employment change, etc.

\section{Regional Cluster Policies in Sweden}

Seeing that economic growth in Sweden is mainly taking place in 'new' industries located in urban regions many of the industries in sparsely populated regions are defined, explicitly or implicitly, as traditional and backward. Attempts to assist these backward regions often mean helping them to 'create' clusters. Porter's plea (1996) for cluster theory to be incorporated in policy making has been heeded at European and national levels. For instance, the Swedish Agency for Economic and Regional Growth (2009) has described the concept of clusters as follows: "Regional clusters work together to achieve competitive advantage. Clusters consist of businesses, public operators and universities from the same geographical area” (author's translation).

Table 2: Analysis of Regional Growth Agreements and Regional Development Programmes in Sweden (RTP and RUP)

\begin{tabular}{lllllll}
\hline County type & County & $\begin{array}{l}\text { No. of } \\
\text { times } \\
\text { clusters are } \\
\text { mentioned }\end{array}$ & $\begin{array}{l}\text { No. of } \\
\text { innovation } \\
\text { systems are } \\
\text { mentioned }\end{array}$ & $\begin{array}{l}\text { Definition } \\
\text { of clusters }\end{array}$ & $\begin{array}{l}\text { Definition } \\
\text { of } \\
\text { innovation } \\
\text { systems }\end{array}$ & $\begin{array}{l}\text { Reference } \\
\text { to research }\end{array}$ \\
\hline Sweden & Stockholm & 44 & 3 & $\mathrm{Y}$ & $\mathrm{Y}$ & $\mathrm{Y}$ \\
MA & Västra & 1 & 0 & $\mathrm{~N}$ & - & $\mathrm{N}$ \\
& Götaland & & & & & $\mathrm{N}$ \\
& Skåne & 5 & 4 & $\mathrm{Y}$ & $\mathrm{N}$ & $\mathrm{N}$ \\
Mid-Sweden & Uppsala & 2 & 2 & $\mathrm{~N}$ & $\mathrm{~N}$ & $\mathrm{~N}$ \\
NMA & Östergötland & 2 & 1 & $\mathrm{~N}$ & $\mathrm{~N}$ & $\mathrm{~N}$ \\
& Halland & 0 & 0 & - & - & - \\
& Örebro & 2 & 2 & $\mathrm{~N}$ & $\mathrm{~N}$ & $\mathrm{~N}$ \\
& Sörmland & 3 & 0 & $\mathrm{~N}$ & - & $\mathrm{N}$ \\
Southern & Västmanland & 3 & 2 & - & - & $\mathrm{N}$ \\
Sweden & Jönköping & 20 & 9 & $\mathrm{Y}$ & $\mathrm{Y}$ & $\mathrm{N}$ \\
NMA & Kalmar & 0 & 0 & - & - & $\mathrm{N}$ \\
& Kronoberg & 3 & 0 & $\mathrm{Y}$ & $\mathrm{N}$ & $\mathrm{N}$ \\
& Blekinge & 4 & 8 & $\mathrm{~N}$ & $\mathrm{~N}$ & $\mathrm{~N}$ \\
& Gotland & 0 & 0 & - & - & $\mathrm{N}$ \\
\multirow{5}{*}{ Northern } & Dalarna & 39 & 5 & $\mathrm{Y}$ & $\mathrm{N}$ & $\mathrm{N}$ \\
Sweden & Gävleborg & 13 & 6 & $\mathrm{Y}$ & $\mathrm{Y}$ & $\mathrm{N}$ \\
& Värmland & 23 & 3 & $\mathrm{Y}$ & $\mathrm{Y}$ & $\mathrm{N}$ \\
& Västerbotten & 4 & 6 & $\mathrm{~N}$ & $\mathrm{~N}$ & $\mathrm{~N}$ \\
& Norrbotten & 5 & 6 & $\mathrm{Y}$ & $\mathrm{Y}$ & $\mathrm{N}$ \\
& Västernorrland & 27 & 0 & $\mathrm{Y}$ & - & $\mathrm{N}$ \\
& Jämtland & 0 & 0 & $\mathrm{~N}$ & - & $\mathrm{N}$ \\
\hline
\end{tabular}

MA: Metropolitan Area - NMA: Non-Metropolitan Area 
It is not just at the national level the idea that cluster formation and innovation can be stimulated, but also on the regional level. In this way, cluster projects are an important and integral part of the current national and regional growth policy in Sweden. One way to examine the use of clusters in policy on regional level is to look at the present regional growth and development programmes (RTP and RUP). An indication of the importance of the concepts of clusters and innovation systems is the number of citations in official documents (Table 2). There are only four out of 21 counties that do not mention clusters or innovation systems at all. These are Jämtland, Halland, Kalmar and Gotland. Those which mention clusters most often are Stockholm (44), Dalarna (39), Västernorrland (27), Värmland (23) and Jönköping (20). Jönköping also use the term innovation systems most often (9).

In terms of content, almost all documents use the concepts of clusters and innovation systems without reference to research and without defining them, and there are also large discrepancies between the documents. In some documents, innovation systems are taken to be about the technique while others refer to the systems of communication and networks. In most cases, there is no mention of research which supports the arguments to encourage cluster and innovation systems development in that particular context.

All documents that use the term cluster make reference to sectors which are already identified, according to the particular definition used in the document, as being important existing, developing or potential clusters. This is exemplified in RUP Värmland: "With cluster we mean a geographically delimited concentration of businesses dependent on each other and that contribute to stronger ability to compete. In our region we can identify some cluster-like concentrations of businesses - The Paper Province, Compare (IT), steel and industry with a number of partial clusters. The strategy aims at strengthening the aforementioned 'clusters'” (Hållbar Värmländsk växtkraft: 13). The concept of clusters has also been defined as follows: "Agglomerations of businesses often develop, so called clusters" (Östgötaregionen 2020 Regionalt utvecklingsprogram: 35) or as “... a strategic competence field (cluster)” (Det kreativa Dalarna: 3).

How viable the goals are is also dependent on the understanding of what clusters are. In the RUP of Gävleborg it is stated that the goal is "...to record ideas for new clusters that are likely to create regional growth” (5 per cent bättre: Tillväxt Gävleborg 2004-2007: 27). This takes the idea of creation of clusters to the point that it is an actual, well defined empirical unit and not an abstract dynamic entity that constitutes the cluster. It also means that it would be possible to create a cluster if the idea is good enough.

The Dalarna RTP links strongly to the national strategy which explicitly draws on the prioritisation of clusters and cluster development: "In Sweden it seems that the national level is determined to continue to stimulate the creation of an active regional and local cluster development strategy. This fact also constitutes an important ingredient in our work to link together local and regional initiatives with national interests and resources. In fact, Dalarna has already started with the work in Triple Steelix to actively use and develop innovation systems” (Det kreativa Dalarna: 3).

Thus, there are three major important findings in the documents. First, it is clear that the concepts of clusters and innovation systems have become important for policy on national and regional levels of government. Second, the understanding of clusters and innovation systems is generally poor. Third, in spite of obvious regional variations 
in preconditions for cluster development, there are no clear regional modifications in the interpretation of clusters as described in the documents.

We started our analysis by asking if policy and planning can help dynamic growth clusters to develop in sparsely populated regions. First of all, it is obvious that cluster theory and policy has been oriented towards urban areas. The focus has been on 'new' industries, rather than on traditional trades like forestry and mining which remain relatively important in non-metropolitan areas. Most industries in traditional sectors have been localized according to old economic paradigms, close to the natural resources. This has meant that there is a path dependency of such industries because of the tremendous capital costs (economic and human) it would entail to move them somewhere else. It would also mean a loss of the labour force with social contacts and networks, skills and know-how - and potential innovation capacity - if they were not to come with the firm. Despite the fact that the forest industry is one of the more innovative industries in Sweden little attention has been paid to this in economic geography. However, Malmberg (2002) argues that these industries are just as inclined to make technological innovations and adjustments as other industries and sectors, as well as engaging their employees in competence developing activities. This path dependency can also explain why there are several forest industry clusters that have evolved through history but no new clusters have developed. In support of Malmberg's (2002) argument it can be argued that dynamic environments have grown and developed spontaneously over a long period of time and are therefore not the outcome of a well planned strategy. In other words, historical development and historical events are important.

It is also obvious that cluster policies rely heavily on Porter's diamond model, agglomeration theory (basically localization and urbanization economies) and experiences from case studies performed on high-tech clusters in relatively densely populated regions (Karlsson 2008). This is rational from several points of views but nevertheless it could be questioned whether these experiences can be implemented in cluster policies targeting development issues in sparsely populated regions far from metropolitan areas. These kinds of obstacles when implementing cluster policies have for instance been discussed by Peck and Lloyd (2008) and Hospers (2005). The ideas about geographical clusters frequently emphasize the importance of factors such as the spatial agglomeration of many firms within a specific field, close contacts with subcontractors, and demanding customers and advanced/specialized supporting functions relatively nearby. Furthermore, the importance of a large pool of specialized labour has been highlighted. Quite often, the need for a critical mass is mentioned. Even though it could be argued that this kind of critical mass under certain conditions could be achieved in highly specialized businesses located in rather small places these criteria are usually much more easily met in metropolitan regions and dense urban areas. Low densities of population and firms, weak physical infrastructure and long distances to metropolitan areas are problematic when sparsely populated regions are trying to accommodate national and international governments to identify, create and stimulate new and existing clusters for regional growth.

From this it could be expected that sparsely populated areas would not be able to accommodate clusters. However, there are some exceptions even in the sparsely populated regions of northern Sweden. These have often developed over a long period of time (as have most successful clusters) and are based on an initial demand from traditional industries such as forestry or mining within the region. Another interesting 
example is the remarkable growth in the testing of cars and components in certain localities in the two northernmost counties (Korsås 2003). Here a number of local entrepreneurs are serving several transnational companies testing their products under harsh winter conditions. The development started already during the 1970s but took off during the 1990s and early 21st century. Today several hundreds of people from the area are involved, in particular during the winter season. Whether or not these businesses could be seen as a cluster might be questioned, but it is a fact that these activities are geographically concentrated to a limited number of municipalities in the north and make an important contribution to the local economy in terms of employment opportunities, investments in testing infrastructure and multiplier effects on local services. What generally characterizes these businesses is that they have been able to make initial use of local circumstances or traditions and further strengthened these competitive advantages by responding to an international demand within their specific niche. An international network and 'pipelines' to key actors at the global level is thus of great importance, not least in order to maintain their innovative capacity.

\section{Concluding Remarks}

Recent findings indicate the need for focusing on knowledge flows to and within local labour markets (Boschma et al. 2008, Eriksson and Lindgren 2008). In order to be competitive, firms must be able to make use of local knowledge, for instance through job changes within the local labour market. Of particular importance is the acquiring of related competences enhancing the skills portfolio of the firm or plant. Applying this reasoning to policy measures on the local or regional level, it should be of relevance to increase the local mobility between firms and/or to stimulate in-migration of labour from other regions bringing with them related competences. This, however, is more easily said than done. To begin with, it is necessary to map the competence needs of local firms and to find out what related and complementary skills could contribute in a positive direction. Secondly, what measures should be taken in order to obtain this, for instance, either by stimulating local mobility between firms or attracting skilled persons from outside. The policy documents at the regional level in Sweden frequently emphasize the need to maintain and establish local and regional networks and cooperation in order to build and strengthen clusters, whereas the importance of labour mobility for knowledge exchange, network creation and innovation processes are rarely mentioned.

Finally, what can we conclude from this? One conclusion might be that regional and local strategies to develop businesses in sparsely populated areas would have more to learn from taking these and other similar examples as a point of departure than experiences drawn from the numerous case-studies on typically high-tech industries located in metropolitan areas usually referenced in the international literature. For this reason there is a need for more empirically based research on the preconditions for cluster development in sparsely populated areas, and a more nuanced policy on regional development allowing for other pathways to economic growth. As it is today, the concepts of cluster and innovation systems in policy on the regional level are used habitually and without references to empirical evidence from relevant geographical settings. 


\section{References}

Asheim, B.T., Coenen, L. and Svensson-Henning, M. 2003. Nordic SMEs and Regional Innovation Systems. Final Report. Department of Social and Economic Geography, Lund University: Lund.

Bathelt, H., Malmberg, A. and Maskell, P. 2004. Clusters and knowledge: Local buzz, global pipelines and the process of knowledge creation. Progress in Human Geography, 28(1), 31-56.

Boschma, R., Eriksson, R., and Lindgren, U. 2008. Labour Mobility, Related Variety and the Performance of Plants: A Swedish Study, 25th DRUID celebration conference, Copenhagen Business School, Denmark, 17-20 June 2008.

Eriksson, R. and Lindgren, U. 2008. Localized mobility clusters: Impacts of labour market externalities on firm performance. Journal of Economic Geography, 9(1), 33-53.

Eriksson, R., Lindgren, U. and Malmberg, G. 2008. Agglomeration mobility: Effects of localisation, urbanisation and scale on job changes. Environment and Planning A, 40(10), 2419-2434.

Hospers, G-J. 2005. Best practices and the dilemma of regional cluster policy in Europe. Tijdschrift voor Economische en Sociale Geografie, 96(4), 452-457.

Karlsson, C. 2008. Introduction, in Handbook of Research on Innovation and Clusters: Cases and Policies, edited by in C. Karlsson. Cheltenham: Edward Elgar, 1-16.

Korsås, C-J. 2003. Testverksamhet m.m. i övre Norrlands Inland - en ny Basindustri. Ds 2003(18), Näringsdepartementet, Stockholm: Fritzes.

Malmberg, A. 2002. Klusterdynamik och Regional Näringslivsutveckling Begreppsdiskussion och Forskningsöversikt. Rapport A2002(008), Östersund: ITPS.

Malmberg, A. and Maskell, P. 2002. The elusive concept of localization economies: Towards a knowledge-based theory of spatial clustering. Environment and Planning A, 34(3), 429-449.

Malmberg, A. and Power, D. 2005. True Clusters / A Severe Case of Conceptual Headache? The Inaugural Nordic Geographers Meeting. Lund, 10-14 May 2005.

Peck, F. and Lloyd, C.E. 2008. Cluster policies and cluster strategies, in Handbook of Research on Innovation and Clusters: Cases and Policies, edited by C. Karlsson. Cheltenham: Edward Elgar, 393-410.

Pettersson, Ö. 2002. Socio-economic dynamics in sparse regional structures. GERUM Kulturgeografi 2002(2), Kulturgeografiska institutionen/SMC, Umeå: Umeå University.

Porter, M. 1990. The Competitive Advantage of Nations. London: Macmillan.

Porter, M. 1996. Competitive advantage, agglomeration economies, and regional policy. International Regional Science Review, 19(1/2), 85-90.

Porter, M. 1998. Clusters and the new economics of competition. Harvard Business Review, 76(6), 77-90.

Porter, M. 2000. Location, competition, and economic development: Local clusters in a global economy. Economic Development Quarterly, 14(1), 15-34.

Sandow, E. and Westin, K. 2010. Preferences for commuting in sparsely populated areas: The case of Sweden. Journal of Transport and Land Use, 2(3/4), 87-107.

Scott, A.J. and Storper M. 2003. Regions, globalization, development. Regional Studies, 37(6/7), 579-593. 
Steinsli, J. and Spilling, O.R. 2004. On the role of small firms in cluster evolution: The case of internet development in Norway during the 1990s. International Journal of Entrepreneurship and Innovation Management, 4(2/3), 194-215.

Swedish Agency for Economic and Regional Growth (2009). Available online at: http://www.tillvaxtverket.se [accessed: 14 June 2010). 